\title{
Fred Nelson (ed): Community Rights, Conservation \& Contested Land: The Politics of Natural Resource Governance in Africa
}

\author{
London: Earthscan 2010. ISBN 9781844079162, Price \$99.95 (hardback). 360 pages
}

Monique Borgerhoff Mulder

Published online: 9 February 2011

(C) The Author(s) 2011. This article is published with open access at Springerlink.com

The mantra of community-based conservation, community based natural resource management, and its many synonyms has dominated much of contemporary practice in conservation and sustainable development over the last two or more decades, but the approach has failed to live up to its promise. Why? Nelson's beautifully balanced collection of regional syntheses and local case studies in southern and eastern Africa draws together the key arguments as to why this might be. The story is strong and clear, the overview chapters are engagingly written, and the case studies are well chosen. The book should be required reading for decision-makers in every donor organization working on natural resource management in Africa.

Essentially, as anticipated by many, the success of decentralizing natural resources depends on the context into which these resources are devolved. At least three proverbial elephants haunt the communally-managed forests, grasslands and lakes of Southern and Eastern Africa. First is national governance: formal policies designed to ensure decentralization mean nothing when there is a fundamental unwillingness at the centre to relinquish control over valuable resources provided "free" by nature. I am not simply talking about peripheral corruption, but rather the structural features of patron-client states in which politics is the preferred route into private business, elite capture is expected, and control of the executive is directly used for that end (from capital city to village alike). The

M. Borgerhoff Mulder ( $\square)$

Department of Anthropology, University of California at Davis,

Davis, USA

e-mail: mborgerhoffmulder@ucdavis.edu second elephant is foreign aid. Reticent to engage in anything political, external donors treat decentralization as a technical challenge, failing to appreciate that devolution of the control over valuable natural resources is typically not in policy-makers' interests. The technical arguments that devolution will increase efficiency and through tax revenue generate public goods ring hollow in the ears of political elites, again from village to capital city, for whom public goods such as tax revenue are not a salient consideration. The third elephant is global commerce and foreign investment, a particularly poignant force given the new worldwide stampede for ever-dwindling natural resources. China, India, the Gulf, Europe and the USA are now investing heavily in African land for the production of timber, food and biofuels, paralleling previous (and ongoing) investments in mining and tourism. The global economy is starting to reach its ecological limits and, as ecological economists have anticipated, the value of natural resources is escalating. With tax honeymoons for the investors and nice pay-offs to politicians at various junctures along the road, how can local communities, even those with officially devolved rights, have any say in the matter?

On the above, generally, there is wide agreement. So why did Nelson put this book together? Because "more effective efforts to promote decentralization, devolution and democratization require a better understanding of governance processes if reform efforts are to have greater impact" (p22). The various authors, all participants in a 2007 meeting of the IUCN Southern Africa Sustainable Use Specialist Group (SASUSG) are not merely academic commentators but, for the most part, project implementers, fundamentally grounded in the day-to-day details of trying to make devolution work. Abstract talk about policy is 
replaced with direct observations on the actions of key players, including members of parliament, bureaucrats, local communities and foreign donors, and the real on-theground distribution of power. There is a lot to learn from the varied experiences of these authors, although it must be said some of the detail is more for the regional specialist than the general reader.

The first section of the book deals with national (Kenya, Tanzania, Namibia and Botswana) level assessments of progress in and barriers against devolved natural resource management. Kenya is the country showing least success in any kind of devolution. Kabiri describes how barriers persist despite radical shifts in policy and players over the colonial and post-colonial eras; particularly interesting is the complete failure to legislate any consumptive use of wildlife by local communities throughout the 1990s, in part because of political deadlock, in part opposition due to a powerful alliance of animal rights groups and photographic tourist operators linked to political players, and in part because of the deeply-embedded expectation that wildlife value is there to be expropriated only by the rich. The story from Tanzania is more nuanced. Nelson and Blomley describe the differential success with devolution in Tanzania's wildlife and forestry sectors, attributing the greater achievements in the latter to the relatively low perceived value of forests, to visionary leadership in the ministry, and to appropriate donor leverage. Rihoy and Maguranyanga describe how even in Botswana, Africa's most stable and prosperous nation, the erstwhile successful community trusts for managing natural resources are currently losing in the tussle for power between centralized protectionist interests and decentralized stakeholders favoring local utilization. In fact it is only in the Namibian case, described by Jones, where we see firmly devolved rights over natural resource management. Here success is attributed to many of factors clearly missing in the other cases - a network of like-minded political actors, a fervent effort to reverse the earlier apartheid discriminative policies that allowed only white farmers to utilize wildlife, a commitment to enshrining these new principles in unambiguous legislation, and tactful engagement by outside non-governmental organizations. Looking more broadly at the whole region, Murombedzi's evaluation is blunt. He concludes that devolution of natural resource management to local communities is "a vehicle for private capital interests".

The second section presents six cases studies that illustrate the more general points in the regional syntheses. Whande uses the case of the Madimbo Corridor in the Great Limpopo Transfrontier Conservation Area to demonstrate how the transfrontier conservation and development model ("Peace Parks") does not lend itself well to genuine devolution through CBNRM. Essentially policy windows whereby communities might co-manage the protected area are constantly being closed, basically because of the greater power of outside forces in biodiversity conservation, national security and sovereignty in these international borderlands.

Rihoy et al. tell the somewhat tragic tale of the collapse of CBNRM in Zimbabwe's Mahenye ward. Operating under the CAMPFIRE CBNRM program, every household in Mahenye was, by the end of the 1990s, earning significant income from the rents paid by safari companies utilizing their village lands. Even the much-lamented tensions between the local CAMPFIRE committees and District Councils eager for revenue had been resolved. Over the last 10 years everything has changed. The sad story of elite capture by a local chief and his relatives can be attributed in part to Zimbabwe's financial collapse, and in part the ruling party's iron grip of the country since 2000, in particular the reestablishment of local chiefs appointed by (and consequently owing heavy allegiance to) the ruling party.

Lubilo and Child describe the trials and tribulations of participatory wildlife governance in Lupande Game Management Area bordering Zambia's South Luangwa National Park. They lay the blame largely at the door of Zambia's neopatrimonial state. Policy shifts of the 1990s towards multiparty transparency that began to shift power to the ordinary people were gradually dismantled as politicians, often linked to business enterprises, undercut the legitimacy of village-based natural resource management. The situation was only exacerbated by international donors favoring support of the central government (through "basket funds") over locally-based projects. Over the last 10 years natural resource devolution became buried in the grave of lack of transparency, democracy and accountability.

Outside agencies, facilitators and funders can indeed be the principle cause of failure. Monjane describes the failures of a CBNRM program in Mahel, southern Mozambique, attributing these directly to the mistakes made by the facilitators. Monjane stresses that supporting NGOs and donor agencies need superb (and not easily acquired) skills in management, planning, mobilization and implementation.

Madzawamuse's account of CBNRM initiatives with the Basarwa/San of Botswana's Okavango Delta highlights how all the aforementioned difficulties with shared governance become more acute when the targeted communities are political and ethnic minorities. Here she argues that a focus on devolution is not enough: outside facilitators, implementing agencies and donors need to employ the language of human rights.

Also considering ethnically or economically marginalized populations, Ngoitiko et al. present a more optimistic analysis of devolution, focusing on the much contested and highly valuable land in Loliondo, Tanzania. Loliondo is spectacularly beautiful, lies adjacent to the Serengeti national park (hosting migrating wildebeest for part of the year), is 
home to many Maasai herding households, and is much sought after by photographic and safari hunting tourist operators as well as agricultural investors. The authors document the constant assaults on Maasai autonomy in the area, ranging from policy shifts affecting where the Maasai can graze their cattle and whether or not they can receive rents directly from tour operators, to state-sanctioned land grabs. In many instances however the local communities have successfully evaded these intrusions, with strategies ranging from passive resistance to sophisticated advocacy, electoral campaigning, productive alliances with NGOs, judicious use of the press, and direct legal challenges.

The challenges to devolved natural resource management are brought into sharp focus in the penultimate chapter, a forward-looking discussion of how to implement Reduced Emissions from Deforestation and Forest Degradation (REDD) in the region. REDD is now seen as a key instrument in slowing global climate change through payments for avoided deforestation, providing a critical missing piece from the Clean Development Mechanism established under the Kyoto protocol. REDD will not work without clearly devolved property rights, such that local communities capture the benefit flows - effectively the cash payments for avoided deforestation that emanate from the North. This is in part because more than $50 \%$ of the world's remaining forests are managed by local communities, and in part because states have such a poor record in successful forest management. The challenge however in effectively linking carbon storage to local community benefits is enormous, insofar as REDD payments will undoubtedly contribute to turning low-value woodlands into a potentially highly valued resource, such that the state and private interests will yet again try to siphon off any profits.

From the aforementioned chapters Nelson reaches two principal conclusions. The first is that there is no inevitable linear trend towards devolution in Southern and Eastern Africa. The radical political changes of the early 1990s, and particularly the ridding of South Africa's racist minority rule, spurred a massive wave of democratization that facilitated the creation of policies allowing for devolved natural resource management. But these policies have for the most part not been implemented. In the last $10-15$ years devolution has stalled, and often reversed. This observation counters the claims of many who believed (and still believe) that devolution is an inevitable process. As such, the reconsolidation of centralized power contrasts dramatically with empty devolutionary rhetoric, and (I think Nelson is correct in pointing out) may be symptomatic of a wider erosion of democratic governance in Africa at present. A somewhat less surprising corollary then of this conclusion is that the macropolitical context shapes the success of CBNRMdevolution is only as good as the institutional framework in which it unfurls. A second conclusion is what Nelson calls the "paradox of the market". Advocates of CBNRM had assumed that the growth of markets for natural resources would motivate local communities into establishing their property rights and sustainably managing their natural resources. While there is some validity in such claims, it is also true that as natural resources become more valuable and hence scarcer, local property rights are undermined by the arrival of powerful external claimants, including the state.

So where do we go from here? Murombedzi's overview chapter makes the point that CBNRM on its own is not enough - it must be coupled with radical land reforms, a sentiment supported by many of the authors who document failed (or failing) devolution initiatives in the region. So how is such reform achieved? Here Nelson's contribution is sparse - essentially two brief recommendations at the end of the final chapter - but on the mark. First donors should shift support from central government (typically provided as basket funds) to local communities (typically projectbased), providing not simply financial resources but also extensive capacity building. This recommendation derives from the belief that the starting point for democratic reforms (that shift power from the centre to the periphery) lies at the centre. Rather, by promoting and assisting change at the local level, donors can spark a more dynamic interaction between centre and periphery, essentially helping the party that typically loses. This is obviously a strategy more easily adopted by NGOs than through intergovernmental agreements. The second recommendation is that devolution should be deployed strategically, promoted at times of instability. In many of the case studies presented the seeds of CBNRM were sown in periods of macropolitical crisis - reforms in South Africa, Namibia, Zimbabwe and Mozambique occurred at the end of long term liberation movements or civil wars, and in Tanzania and Zambia during shifts to political pluralism. Indeed, the studies in this volume show that periods of political stability are bad for decentralization as in such times of relative comfort political and business interests become deeply reentrenched. Thus, rather counter-intuitively, Nelson proposes that donors build social and political capacity during stable periods, thereby ensuring communities are ready to strategize for reforms during windows of political instability and change.

There is a danger that conservationists engaged in the debates over protection versus utilization, or centralized versus decentralized management, will conclude from this volume (somewhat smugly) that devolution and CBNRM has not worked, and that we should go back to supporting old-fashioned protectionism. The message from this book is clear, if not explicitly made - we should not give up on devolution, despite the litany of problems depicted in these chapters. Interestingly Rihoy et al. still view the CAMPFIRE programme as having successfully empowered local Zimbabweans with knowledge, incentives and organizational abilities with which to identify their problems and puzzle out 
solutions. Furthermore they note the enduring strength of CAMPFIRE's institutional design — rural district councils that were once seen as a rapacious predator on community rents provide, in the present situation, a potential system of checks and balances whereby corrupt chiefs who co-opt the local CAMPFIRE organization can potentially be brought under control. Similarly Ngoitiko et al. also describe clearly how each step in the struggle over Loliondo real estate has served to empower local communities, sometimes bringing erstwhile opposed clans together. In short, temporary barriers (including the policy reversals we are seeing all over the region) reflect current political realities, but they also ultimately serve to sharpen the tools of the dispossessed.

Finally what does this book do for the field of human ecology? Strangely, although the argument is all about politics, the term political ecology (a large subfield of human ecology) appears not once in the volume. I suppose terms fall in and out of fashion, but if you view yourself a political ecologist, you should read this book. Conceptually the field is also moving forward. Twenty years ago we were all thinking about communities benefiting from the management of wildlife (community-based conservation), then we moved towards community management of the full suite of natural resources (CBRNM), and now we are calling for complete devolution (of land and ultimately power).
Indeed the management of increasingly scarce and valuable natural resources is becoming a crucible for thinking about social and political evolution more generally. Finally, although this book is not aimed at theory development within human ecology, some interesting observations emerge. First, there is clear evidence of how earlier institutional frameworks shape current outcomes: in Namibia and to some extent in Zimbabwe, the laws that allowed white minority farmers to utilize wildlife on their lands have persisted-facilitating CBNRM. Second, it is very clear how strongly the dominant global discourses on sustainability and community participation have shaped policy developments in each of the nations of this region. Lastly there is always a role for great men and women, irrespective of the institutional context-in almost all of the chapters enlightened administrators, policy makers, and personnel in aid organizations play a critical role (good and bad) in both national and local struggles.

Open Access This article is distributed under the terms of the Creative Commons Attribution Noncommercial License which permits any noncommercial use, distribution, and reproduction in any medium, provided the original author(s) and source are credited. 